\title{
RhoA downstream of $G_{q}$ and $G_{12 / 13}$ Pathways regulates Protease- activated Receptor-mediated dense granule release in platelets
}

\author{
Jianguo Jin ${ }^{a, c}$, Yingying Mao ${ }^{a}$, Dafydd Thomas ${ }^{b}$, Soochong Kim ${ }^{a, c}$, James L. Daniel ${ }^{b, c}$, and \\ Satya P. Kunapulia,b,c \\ a Department of Physiology, Temple University School of Medicine, Philadelphia, PA \\ ${ }^{b}$ Department of Pharmacology, Temple University School of Medicine, Philadelphia, PA \\ c The Sol Sherry Thrombosis Research Center, Temple University School of Medicine, Philadelphia, \\ PA
}

\begin{abstract}
Platelet secretion is an important physiological event in hemostasis. The protease activated receptors, PAR 1 and PAR 4, and the thromboxane receptor activate the $G_{12 / 13}$ pathways, in addition to the $\mathrm{G}_{\mathrm{q}}$ pathways. Here, we investigated the contribution of $\mathrm{G}_{12 / 13}$ pathways to platelet dense granule release. 2MeSADP, which does not activate $\mathrm{G}_{12 / 13}$ pathways, does not cause dense granule release in aspirin-treated platelets. However, supplementing 2MeSADP with YFLLRNP $(60 \mu \mathrm{M})$, as selective activator of $\mathrm{G}_{12 / 13}$ pathways, resulted in dense granule release. Similarly, supplementing PLC activation with G12/13 stimulation also leads to dense granule release. These results demonstrate that supplemental signaling from $G_{12 / 13}$ is required for $G_{q}$-mediated dense granule release and that ADP fails to cause dense granule release because the platelet $\mathrm{P} 2 \mathrm{Y}$ receptors, although activate PLC, do not activate $\mathrm{G}_{12 / 13}$ pathways. When RhoA, downstream signaling molecule in $\mathrm{G}_{12 / 13}$ pathways, is blocked, PAR-mediated dense granule release is inhibited. Furthermore, ADP activated Rho A downstream of Gq and upstream of PLC. Finally, Rho A regulated PKC $\delta$ T505 phosphorylation, suggesting that Rho A pathways contribute to platelet secretion through $\mathrm{PKC} \delta$ activation. We conclude that $\mathrm{G}_{12 / 13}$ pathways, through RhoA, regulate dense granule release and fibrinogen receptor activation in platelets.
\end{abstract}

\section{Keywords \\ platelet secretion; dense granule; $\mathrm{G}_{12 / 13}$; ADP; RhoA}

\section{Introduction}

Platelets are an important part of the hemostatic mechanism that are activated following vascular injury[1,2]. Numerous agonists, such as thrombin and ADP, cause platelet activation through stimulation of G protein pathways [3-8]. Upon activation, platelets secrete their granule contents that help amplify platelet responses to many of the physiological agonists

Corresponding Author: Satya P. Kunapuli, Ph.D., Department of Physiology, Temple University, Department of Physiology-Rm. 224, OMS, 3420 N. Broad Street, Philadelphia, Pennsylvania 19140 USA, Phone: (215) 707-4615, Fax: (215) 707-4003, E-mail: spk@temple.edu.

Publisher's Disclaimer: This is a PDF file of an unedited manuscript that has been accepted for publication. As a service to our customers we are providing this early version of the manuscript. The manuscript will undergo copyediting, typesetting, and review of the resulting proof before it is published in its final citable form. Please note that during the production process errors may be discovered which could affect the content, and all legal disclaimers that apply to the journal pertain. 
[9]. Human platelets contain two types of storage granules, $\alpha$-granules and dense granules. Substances released from the $\alpha$-granules supplement thrombin generation at the site of vascular injury $[9,10]$. ADP is the most important constituent of the dense granules that is essential for recruiting platelets to the site of vascular injury[11,12].

Platelets express a number of heterotrimeric $G$ proteins, including $\mathrm{G}_{\mathrm{q}}, \mathrm{G}_{12}, \mathrm{G}_{13}$, and $\mathrm{G}_{\mathrm{i}}[6,13$, 14]. Protease-activated receptors (PARs) and thromboxane receptors couple to $\mathrm{G}_{\mathrm{q}}$ as well as $\mathrm{G}_{12 / 13}[11,12]$, whereas ADP activates $\mathrm{Gq}$ and Gi pathways through the $\mathrm{P}_{2} \mathrm{Y}_{1}$ and $\mathrm{P} 2 \mathrm{Y}_{12}$ receptors, respectively[15]. Downstream of these $\mathrm{G}$ protein-coupled receptor stimulation, $\mathrm{G}_{\mathrm{q}}$ is known to be important for platelet secretion[16]. In platelets deficient in $\mathrm{G} \alpha_{\mathrm{q}}$ or phospholipase $\mathrm{C}-\beta_{2}\left(\mathrm{PLC} \beta_{2}\right)$, stimulation with thrombin and thromboxane $\mathrm{A}_{2}\left(\mathrm{TxA}_{2}\right)$ results in markedly decreased platelet secretion [16-18]. Similarly, collagen fails to cause dense granule secretion in PLC $\gamma_{2}$-deficient platelets[19]. Activation of PLC leads to generation of inositol 1,4,5 triphosphate $\left(\mathrm{IP}_{3}\right)$ and diacylglycerol (DAG) $[18,20]$ and platelet dense granule secretion is dependent on the $\mathrm{IP}_{3}$-induced rise in intracellular calcium and DAG-induced activation of protein kinase $\mathrm{C}$ (PKC) $[21,22]$.

It is known that stronger platelet agonists like thrombin, protease-activated receptor-1 (PAR1) activating peptide SFLLRN, protease-activated receptor-4 (PAR4) activating peptide AYPGKF and thromboxane $A_{2}$ analogue (U46619) cause dense granule secretion. However, weaker agonists like ADP fail to cause dense granule secretion when thromboxane generation is blocked[4]. ADP, through activation of the P2 $Y_{1}$ receptor, stimulates $G_{q}$ and $P L C \beta_{2}$, and causes increases in intracellular calcium and PKC activation [15,16,23-25], but fails to cause dense granule secretion[4]. Our investigation focuses on why some agonists cause dense granule release whilst others do not even though both agonists activate PLC. Specifically, what are the signaling differences between ADP and U46619 or thrombin that account for the lack of dense granule release by ADP? It is only recently that we began to clearly understand the signaling events downstream of agonist receptors. In $\mathrm{G}_{\mathrm{q}}$-deficient mouse platelets, $\mathrm{U} 46619$ or thrombin, but not ADP, causes shape change through activation of $\mathrm{G}_{12 / 13}$ and RhoA-mediated p160ROCK pathways[26,27]. Hence it is now clear that receptors for thrombin and thromboxane $A_{2}$ couple to $G_{12 / 13}$, in addition to $G_{q}$. Could the inability of ADP to couple to $\mathrm{G}_{12 / 13}$ explain its inability to cause dense granule release? Offermanns and co-workers have shown that $\mathrm{G \alpha}_{13}$ deficient mice have a severe defect in primary hemostasis and complete protection against arterial thrombosis in vivo[16] [27]. In addition these mouse platelets have defective agonist-induced dense granule release[27]. Thus we investigated the role of $\mathrm{G}_{12 / 13}$ pathways in agonist-induced dense granule release using complementary approaches.

In this study, we demonstrate that ADP causes dense granule release in aspirin-treated platelets when supplemented with selective activation of $\mathrm{G}_{12 / 13}$ pathways. In addition, we show that $\mathrm{G}_{12 / 13}$ pathways contribute to dense granule release partially through RhoA pathways. We also provide evidence for the PLC independent activation of Rho A pathways downstream of Gq stimulation. Here, we suggest that at least one reason ADP fails to cause dense granule secretion is its inability to activate $\mathrm{G}_{12 / 13}$ signaling pathways.

\section{Materials and Methods}

\subsection{Materials}

Apyrase (Type VII), fibrinogen (Type 1), bovine serum albumin (fraction V), 2MeSADP, were obtained from Sigma (St. Louis, MO). Chrono-lume reagent was purchased from Chrono-Log Corp. (Havertown, PA). AYPGKF and YFLLRNP were obtained from New England Peptide (Gardner, MA). YM254890 was a gift from Yamanouchi Pharmaceutical Co., Ltd. (Ibaraki, Japan). m-3M3FBS was purchased from Calbiochem, Inc.( San Diego, CA). Exoenzyme C3 Transferase was obtained from Cytoskeleton Inc. (Denver, CO). PKC $\delta$ isoform selective 
antibodies were obtained from Santa Cruz Biotechnologies (Santa Cruz, CA). ALL the other reagents were of reagent grade and bought from Sigma (St. Louis, MO).

\subsection{Isolation of human platelets}

Whole blood was drawn from healthy, consenting human volunteers into tubes containing onesixth volume of ACD (2.5 g of sodium citrate, $1.5 \mathrm{~g}$ of citric acid, and $2 \mathrm{~g}$ of glucose in 100 $\mathrm{ml}$ of deionized water). Blood was centrifuged (Eppendorf 5810R centrifuge, Hamburg, Germany) at $230 \times g$ for $20 \mathrm{~min}$ at room temperature to obtain platelet-rich plasma (PRP). PRP was incubated with $1 \mathrm{mM}$ acetylsalicylic acid for $30 \mathrm{~min}$ at $37^{\circ} \mathrm{C}$. The PRP was then centrifuged for $10 \mathrm{~min}$ at $980 \times \mathrm{g}$ at room temperature to pellet the platelets. Platelets were resuspended in Tyrode's buffer $(138 \mathrm{mM} \mathrm{NaCl}, 2.7 \mathrm{mM} \mathrm{KCl}, 1 \mathrm{mM} \mathrm{MgCl} 2,3 \mathrm{mM}$ $\mathrm{NaH}_{2} \mathrm{PO}_{4}, 5 \mathrm{mM}$ glucose, $10 \mathrm{mM}$ Hepes, $\mathrm{pH} 7.4,0.2 \%$ bovine serum albumin) containing $0.01 \mathrm{U} / \mathrm{ml}$ apyrase. Cells were counted using the Coulter Z1 Particle Counter and concentration of cells was adjusted to $2 \times 10^{8}$ platelets $/ \mathrm{ml}$. All experiments using washed platelets were performed in the absence of extra cellular calcium unless otherwise mentioned.

\subsection{ADP-ribosylation of RhoA by exoenzyme C3 Transferase}

Platelet-rich Plasma was obtained from ACD buffed blood by centrifugation at 230g for 20 $\mathrm{min}$ at ambient temperature. Platelets, free of reticulocytes and other contaminants, were isolated from plasma by centrifugation at $980 \times \mathrm{g}$ for $10 \mathrm{~min}$ and re-suspended in Tyrode's buffer with $0.01 \mathrm{U} / \mathrm{ml}$ apyrase, $1 \mathrm{mM}$ acetylsalicylic acid and with or without $20 \mu \mathrm{g} / \mathrm{ml}$ exoenzyme $\mathrm{C} 3$ transferase $\left(2 \times 10^{8}\right.$ cells $\left./ \mathrm{ml}\right)$, and incubated at $37^{\circ} \mathrm{C}$ for 4 hours. Finally the platelet count was adjusted to $1.5 \times 10^{8}$ cells $/ \mathrm{ml}$.

\subsection{Measurement of platelet secretion}

Platelet secretion was determined by measuring the release of ATP using the lumichrome reagent. The activation of platelets was performed in a lumi-aggregometer at $37^{\circ} \mathrm{C}$ with stirring at 900rpm and the secretion was measured and expressed as nmoles of ATP released $/ 10^{8}$ platelets. In experiments where inhibitors were used, the platelet sample was incubated with the inhibitors for 10 minutes at $37^{\circ} \mathrm{C}$ prior to the addition of agonists. The secretion was subsequently measured as described above.

\subsection{Aggregometry}

Aggregation of $0.5 \mathrm{~mL}$ washed platelets was analyzed using a P.I.C.A. lumi-aggregometer (Chrono-log Corp., Havertown, PA). Aggregation was measured using light transmission under stirring conditions $(900 \mathrm{rpm})$ at $37^{\circ} \mathrm{C}$. Agonists were added simultaneously for platelet stimulation, each sample was allowed to aggregate for at least 3 minutes. The chart recorder (Kipp and Zonen, Bohemia, NY) was set for $0.2 \mathrm{~mm} / \mathrm{s}$.

\subsection{RhoA GST-Pulldown studies}

Synthesis of GST-Rhotekin-RBD was performed according to Ren and Schwartz [28] with some minor modifications. Protein expression was then induced by $100 \mu \mathrm{M}$ isopropyl- $\beta$-Dthiogalactopyranoside (IPTG) (Research Products international, Prospect. IL) treatment for 3 hours at $30^{\circ} \mathrm{C}$.

For RhoA activation assays, platelets were resuspended in HEPES buffered Tyrodes at $3 \times 10^{8}$ cells $/ \mathrm{ml}$ containing 0.4 units $/ \mathrm{ml}$ apyrase. One $\mathrm{ml}$ of platelets per sample was then treated with 1 minute preincubation with GR 144053 at $37^{\circ} \mathrm{C}$ to prevent platelet aggregation. Platelets were then lysed with lysis buffer (100mM Tris, $\mathrm{pH} 7.5,2 \%$ Triton X-100, $1 \%$ Sodium deoxycholate, $0.1 \%$ Sodium Dodecyl Sulfate, $1 \mathrm{M} \mathrm{NaCl}, 20 \mathrm{mM} \mathrm{MgCl}_{2}, 20 \mu \mathrm{g} / \mathrm{ml}$ leupeptin, $2 \mathrm{mM}$ PMSF), snap frozen, thawed on ice and spun at $13,000 \mathrm{~g}$ for 10 minutes at $4{ }^{\circ} \mathrm{C}$. Lysates 
were then treated as described by Ren and Schwartz[28], separated via SDS/Poly Acrylamide Gel Electrophoresis (PAGE, 15\% acrylamide), blotted onto Immobilon-P ( Millipore, Billerica, MA), blocked with 5\% non-fat milk/0.5\% Tween in Tris buffered saline and active RhoA was detected using anti-Rho clone 55 monoclonal antibody (Millipore, Billerica, MA), appropriate HRP-conjugated secondary antibody (Santa Cruz, Santa Cruz, CA), and Immobilon Western chemiluminescent substrate (Millipore, Billerica, MA)

\subsection{Western blot analysis}

Platelets were stimulated with agonists in the presence or absence of inhibitors for the appropriate time, and the reaction was stopped by the addition of 3 X SDS Laemmlli's buffer. Platelet samples were boiled for 10 minutes and proteins were separated by $10 \%$ SDSpolyacrylamide gel electrophoresis and transferred onto polyvinylidene difluoride (PVDF) membrane. Non-specific binding sites were blocked by incubation in Tris-buffered salineTween (TBST; $20 \mathrm{mM}$ Tris, $140 \mathrm{mM} \mathrm{NaCl}, 0.1 \%$ (v/v) Tween 20) containing 2\% (w/v) bovine serum albumin (BSA) for 30 minutes at room temperature, and membranes were incubated overnight at $4{ }^{\circ} \mathrm{C}$ with the primary antibody (1:1000 dilution in TBST with $2 \%$ BSA) with gentle agitation. After three washes for 5 minutes each with TBST, the membranes were probed with an alkaline phosphatase-labeled secondary antibody (1:5000 dilution in TBST with $2 \%$ BSA) for 1 hour at room temperature. After additional washing steps, membranes were then incubated with CDP-Star chemiluminescent substrate (Tropix, Bedford, MA) for 10 minutes at room temperature and immunoreactivity was detected using a Fuji Film Luminescent Image Analyzer (LAS-1000 CH, Japan).

\section{Results}

\subsection{Effect of $\mathrm{G}_{12 / 13}$ activation on 2 MeSADP-induced platelet dense granule release}

As a difference in signaling between ADP and thrombin in platelets is the activation of $\mathrm{G}_{12 / 13}$ pathways, we investigated the effect of selective activation of $\mathrm{G}_{12 / 13}$ pathways on ADPinduced dense granule release. YFLLRNP, a partial PAR1 agonist, only activates $\mathrm{G}_{12 / 13}$ pathway at low concentrations[29,30]. We stimulated washed and aspirin-treated human platelets with ADP and/or YFLLRNP and evaluated platelet functional responses. 2MeSADP activating Gq-coupled $\mathrm{P} 2 \mathrm{Y}_{1}$ and $\mathrm{G}_{\mathrm{i}}$-coupled $\mathrm{P} 2 \mathrm{Y}_{12}$, but not $\mathrm{G}_{12 / 13}$ pathway, caused platelet aggregation, but could not cause dense granule release (Fig. 1). YFLLRNP $(60 \mu \mathrm{M})$, which selectively activates only $\mathrm{G}_{12 / 13}$ pathways, caused platelet shape change, but not aggregation or dense granule release (Fig. 1). However, $100 \mathrm{nM} 2 \mathrm{MeSADP}$ together with $60 \mu \mathrm{M}$ YFLLRNP induced dense granule release in platelets (Fig. 1B). In addition, $60 \mu \mathrm{M}$ YFLLRNP potentiated 2MeSADP-induced platelet aggregation (Fig. 1A). These data indicate that $\mathrm{G}_{12 / 13}$ pathways contribute to dense granule release and aggregation in platelets.

\subsection{Effect of selective activation of Phospholipase $C$ and $G_{12 / 13}$ pathways on platelet dense granule release}

PAR stimulation in platelets leads to stimulation of $\mathrm{G}_{\mathrm{q}}$ and $\mathrm{G}_{12 / 13}$ pathways. Downstream of $\mathrm{G}_{\mathrm{q}}$, PLC is activated resulting in increased intracellular calcium and activation of protein kinase $\mathrm{C}$ isoforms, both of which are reported to be important for dense granule release. Phospholipase $\mathrm{C}$ can be directly activated by m-3M3FBS [31,32]. We evaluated the effect of selective $\mathrm{G}_{12 / 13}$ signaling and selective Phospholipase $\mathrm{C}$ activation on dense granule release using two strategies. In both approaches, $\mathrm{G}_{\mathrm{q}}$ signaling is completely abolished. First, we used a $\mathrm{G}_{\mathrm{q}}$ inhibitor $\mathrm{YM} 254890[33,34]$, to completely block $\mathrm{G}_{\mathrm{q}}$ pathways. Under these conditions, activation of human platelets with AYPGKF results in selective activation of $\mathrm{G}_{12 / 13}$ pathways. We have established the conditions and demonstrated the specificity of the YM254890 in our recent publication[35]. As shown in Fig. 2, in the YM254890 treated human platelets, AYPGKF caused shape change (Fig. 2A), but not aggregation (Fig. 2A) or dense granule 
release (Fig. 2B). Selective activation of PLC using m-3M3FBS $(80 \mu \mathrm{M})$ resulted in a small shape change (Fig. 2A), but not aggregation (Fig. 2A) or dense granule release (Fig. 2B). However, combined stimulation of $\mathrm{G}_{12 / 13}$ pathways and PLC resulted in platelet aggregation (Fig. 2A) and dense granule release (Fig. 2B), under conditions of $\mathrm{G}_{\mathrm{q}}$ blockade. These results indicate that $\mathrm{G}_{12 / 13}$ pathways contribute to both platelet aggregation and dense granule release.

In the second approach we used platelets from mice lacking $\mathrm{Ga}_{\mathrm{q}}$. Thrombin fails to cause platelet aggregation, dense granule release, or intracellular calcium mobilization in these platelets[16]. As shown in Fig. 3A, stimulation of platelets from $\mathrm{G} \alpha_{\mathrm{q}}$ null mice with AYPGKF resulted in shape change but not aggregation or dense granule release. Similarly, selective PLC activation with $80 \mu \mathrm{M} \mathrm{m}$-3M3FBS caused only shape change in these platelets (Fig. 3A). However, stimulation of $\mathrm{G} \alpha_{\mathrm{q}}$ null mouse platelets with AYPGKF and $\mathrm{m}-3 \mathrm{M} 3 \mathrm{FBS}$ resulted in platelet aggregation and dense granule release (Fig. $3 A$ \& B), indicating that $\mathrm{G}_{12 / 13}$ pathways contribute to platelet aggregation and dense granule release.

In both approaches, we limited the concentration of m-3M3FBS to $80 \mu \mathrm{M}$ as at this concentration we observed only shape change without aggregation or dense granule release. However, when we used higher concentrations of m-3M3FBS, platelet aggregation and dense granule release were observed (data not shown).

Our recent studies and other's have shown that co-stimulation of $\mathrm{G}_{12 / 13}$ and $\mathrm{G}_{\mathrm{i}}$ or $\mathrm{G}_{\mathrm{z}}$ pathways leads to a small raise in intracellular calcium and aggregation [36,37]. Hence, it is possible that co-stimulation of $G_{12 / 13}$ and $G_{i}$ or $G_{z}$ pathways may be sufficient to cause dense granule release. We stimulated platelets from $\mathrm{Ga}_{\mathrm{q}}$ null mice with 2MeSADP and AYPGKF together. In these platelets $2 \mathrm{MeSADP}$ activates only $\mathrm{G}_{\mathrm{i}}$ pathways and AYPGKF activates only $\mathrm{G}_{12 / 13}$ pathways[38]. Although selective stimulation of Gi or G12/13 with 2MeSADP or AYPGKF, respectively, in these murine platelets failed to cause any aggregation, combined stimulation of Gi and G12/13 pathways resulted in platelet aggregation (Fig. 3C). As shown in Fig. 3D, selective activation of $\mathrm{G}_{12 / 13}$ and $\mathrm{G}_{\mathrm{i}}$ pathways did not result in dense granule secretion indicating the importance of $\mathrm{G}_{\mathrm{q}}$ pathways in this event.

\subsection{Role of RhoA in dense granule secretion}

As stimulation of $\mathrm{G}_{12 / 13}$ pathways is known to cause activation of RhoA [26,39], we evaluated the role of RhoA using pharmacological inhibitor, exoenzyme C3 transferase[40]. When platelets were pretreated with exoenzyme $\mathrm{C} 3$ transferase for $4 \mathrm{hrs}$, we evaluated the effectiveness of RhoA inhibition using shape change as a read out. Since it is known that RhoA activation occurs downstream of $\mathrm{G}_{12 / 13}$ pathways and that this signaling molecule contributes to shape change in the absence of $\mathrm{G}_{\mathrm{q}}$ pathways, we blocked $\mathrm{G}_{\mathrm{q}}$ pathways with YM254890 and evaluated the effect of $\mathrm{C} 3$ exoenzyme[41] treatment on AYPGKF-induced platelet shape change. When Gq pathways are blocked, AYPGKF caused platelet shape change through $\mathrm{G}_{12 / 13}$-RhoA pathways in control platelets (Fig. 4A). As seen in Fig. 4A, exoenzyme C3 transferase treatment completely blocked this RhoA mediated platelet shape change in these platelets, indicating that exoenzyme C 3 transferase completely inhibited Rho A under our experimental conditions. When platelets were pretreated with exoenzyme $\mathrm{C} 3$ transferase, PARmediated platelet aggregation was inhibited compared to control platelets (Fig. 4B). We also observed that the AYPGKF-induced dense granule release reaction was inhibited by exoenzyme $\mathrm{C} 3$ transferase treatment (Fig. 4C). Similar inhibition by exoenzyme $\mathrm{C} 3$ transferase was seen for thrombin, SFLLRN-, or AYPGKF-induced dense granule release (Fig. 4D). These data indicate that Rho A plays an important role in platelet dense granule release. 


\subsection{Rho A stimulation downstream of Gq pathways in platelets}

Although it has been known that G12/13 and Gq pathways independently activate Rho A $[26,39,42]$, the role of PLC downstream of Gq pathways in the activation of Rho A has not been addressed. Similarly, we have shown that ADP, through the P2Y1 receptor, causes calcium-independent shape change through p160ROCK pathways using pharmacological inhibitors [43]. However, the mechanism of Rho A activation downstream of the P2Y1 receptor is not established. Hence we investigated whether ADP causes Rho A activation and the initial signaling steps contributing to its activation in platelets. As shown in Fig. 5A, Rho A was activated upon stimulation of platelets with $2 \mathrm{MeSADP}$ and this activation was inhibited by a Gq inhibitor YM-254890, suggesting that Rho A activation downstream of the P2Y1 receptor requires Gq stimulation. As shown in Fig. 5B, PLC inhibitor U73122 did not affect 2-MeSADPinduced Rho A activation indicating that Rho A activation occurs upstream of PLC and downstream of Gq stimulation. These data clearly show that ADP, through the P2Y1 receptor, activates Rho A. Thus, Rho A activation occurs in platelets through both Gq and G12/13 pathways.

\subsection{Regulation of Protein Kinase $\mathbf{C} \delta$ by Rho A pathways}

We and others have shown that PAR-mediated dense granule release is regulated by the PKC $\delta$ isoform $[44,45]$. Hence we investigated whether G12/13 pathways regulate dense granule release through regulating the activity of $\mathrm{PKC} \delta$, by analyzing the activation-dependent phosphorylation of the threonine 505 residue as a measure of the activation of PKC [46-50]. As shown in Fig. 6, exoenzyme C3 transferase inhibited PAR-mediated PKC $\delta$ Thr 505 phosphorylation, indicating that RhoA regulates $\mathrm{PKC} \delta$ activity. As PKC $\delta$ is known to play a positive role in PAR-mediated dense granule release [45], G12/13 pathways, through RhoA, thus regulate dense granule release by modulating PKC $\delta$ activity.

\section{Discussion}

In this study we addressed a long-standing question in platelet physiology regarding dense granule release. Of the several physiological platelet agonists, thrombin, thromboxane A2, and collagen cause platelet dense granule release independently of thromboxane generation, whereas other agonists, mainly ADP, do not cause dense granule secretion when thromboxane generation is blocked. The reason for this difference between ADP and strong agonists is not understood to date.

A number of platelet agonists stimulate phospholipase $C \beta 2$ through $\mathrm{G}_{\mathrm{q}}$ activation resulting in an increase in intracellular concentrations of inositol-1,4,5-trisphosphate and diacylglycerol $[18,20]$. The formation of inositol-1,4,5-trisphosphate induces an increase in the cytosolic concentration of $\mathrm{Ca}^{2+}$ while the release of diacylglycerol activates PKC isoforms[20,51,52]. The intracellular signaling events contributing to platelet secretion have been identified as an increase in intracellular calcium and activation of PKC, down stream events of phospholipase $\mathrm{C}$ activation[21,22]. We demonstrated that the PKC $\delta$ isoform plays an important role in regulating PAR-mediated dense granule secretion in human platelets [45]. Both G proteincoupled receptor (GPCR) and GPVI signaling pathways lead to activation of PKC $\delta$. However, there are significant differences in the functional role of PKC $\delta$ downstream of PAR and GPVI signaling in platelets as demonstrated in our previous studies [45].

In human platelets deficient in $\mathrm{G}_{\mathrm{q}}$ or $\mathrm{PLC} \beta_{2}$, thrombin and $\mathrm{U} 46619$ stimulation results in markedly decreased platelet secretion[18]. Similarly, $\mathrm{G}_{\mathrm{q}}$-deficient mouse platelets do not secrete in response to U46619 or thrombin[16]. Finally, collagen failed to cause dense granule release in PLC $\gamma 2$-deficient mouse platelets[19]. These studies established the role of $\mathrm{G}_{\mathrm{q}}$, $P L C \beta_{2}$, intracellular calcium increases, and PKC activation as important signaling molecules 
in U46619- or thrombin-induced platelet dense granule release. However, an important question remained unanswered. ADP, through activation of the $\mathrm{P} 2 \mathrm{Y}_{1}$ receptor stimulates $\mathrm{G}_{\mathrm{q}}$ and $\mathrm{PLC}_{2}$, and causes increases in intracellular calcium and activation of PKC $[15,16,23,25$, 53], but fails to cause dense granule release in platelets under the conditions of thromboxane $\mathrm{A}_{2}$ generation blockade[4]. What are the signaling differences between ADP and U46619 or thrombin that account for the lack of dense granule release by ADP?

It is known that Gq-signaling is required for platelet secretion[16]. Hence, we evaluated the role of $\mathrm{G}_{12 / 13}$ pathways in dense granule release in platelets. We rationalized that because thromboxane $A_{2}$ and thrombin can activate both $G_{q}$ and $G_{12 / 13}$, they cause platelet dense granule release, whereas ADP fails to cause platelet secretion from dense granules because it does not activate $\mathrm{G}_{12 / 13}$.

We used three independent strategies to evaluate the effect of $G_{12 / 13}$ pathways on $G_{q}$ and PLC mediated effects in platelets. We have previously established the conditions for the use of YFLLRNP as a selective agonist for $\mathrm{G}_{12 / 13}$ pathway stimulation in platelets[36]. Supplementing $\mathrm{G}_{12 / 13}$ pathway activation resulted in dense granule release by ADP indicating that $\mathrm{G}_{12 / 13}$ pathways contribute to platelet dense granule secretion. In addition, we blocked $\mathrm{G}_{\mathrm{q}}$ pathways with YM254890 or used platelets from mice lacking $\mathrm{G} \alpha_{\mathrm{q}}$, and selectively stimulated $\mathrm{G}_{12 / 13}$ pathways with AYPGKF. Under these conditions of selective $\mathrm{G}_{12 / 13}$ stimulation, limited activation of PLC resulted dense granule release, although limited PLC activation alone failed to cause dense granule secretion. The potentiation of ADP-induced platelet aggregation by $\mathrm{G}_{12 / 13}$ pathways could be either because of their direct effect on fibrinogen receptor activation pathways[36] or due to positive feedback from the secreted ADP. These results demonstrated the role of $\mathrm{G}_{12 / 13}$ pathways in dense granule release.

$\mathrm{G}_{\mathrm{q}}$ pathways are absolutely required for dense granule release as this event does not occur in $\mathrm{G} \alpha_{\mathrm{q}}$ null mouse platelets or when $\mathrm{G}_{\mathrm{q}}$ pathways are blocked with an inhibitor. Furthermore, when PLC is activated strongly by m-3M3FBS, we observed dense granule release without supplementation of $\mathrm{G}_{12 / 13}$ pathways. These results indicate that when the $\mathrm{G}_{\mathrm{q}}-\mathrm{PLC}$ axis is strongly stimulated dense granule secretion occurs independently of $\mathrm{G}_{12 / 13}$ pathways. Under these conditions, the $\mathrm{G}_{12 / 13}$ pathways may not potentiate the dense granule release. This conclusion is consistent with the observations of Offermanns and co-workers that thrombininduced dense granule release was unaffected in $\mathrm{G} \alpha_{12} / \mathrm{G}_{13}$ null mouse platelets[27]. We interpret that in these mouse platelets, strong stimulation of $\mathrm{G}_{\mathrm{q}}$ pathways by thrombin eliminated the potentiating effect of $\mathrm{G}_{12 / 13}$ pathways on dense granule release. We predict that a concentration-response curve in these mice would probably reveal a right ward shift compared to wild-type mouse platelets at lower concentrations.

Downstream of $\mathrm{G}_{12 / 13}$ pathways RhoA was established as an important signaling molecule that has an effect in platelet shape change [54]. Our studies with a pharmacological inhibitor indicate that RhoA contributes to PAR-mediated dense granule release as well as platelet aggregation. We interpret that such effect could involve direct contribution to dense granule release and hence an apparent role in $\alpha \operatorname{IIb} \beta 3$ integrin activation. Previous studies from Leng et al [55] have implied that RhoA does not contribute to SFLLRN-induced fibrinogen receptor activation. We believe that there may be some differences in the experimental conditions, including the reagent used, that explain the contradicting data from our lab and Leng et al [55].

One question arises from these data is that why elimination of $\mathrm{G}_{12 / 13}$ pathways in mice has no effect on maximal $\mathrm{G}_{\mathrm{q}}$-mediated dense granule release [27], but blockade of downstream signaling molecules, viz. RhoA results in an inhibition. Our studies have revealed for the first time that RhoA pathways could be activated downstream of $\mathrm{G}_{\mathrm{q}}$ as well (Fig. 5). Hence, when 
platelets are stimulated with ADP, the RhoA pathway is activated contributing to calciumindependent platelet shape change. Thus, as outlined in Fig. 7, RhoA pathways are activated downstream of both $\mathrm{G}_{\mathrm{q}}$ and $\mathrm{G}_{12 / 13}$ pathways and maximal stimulation of $\mathrm{G}_{\mathrm{q}}$ alleviates the need for these signaling molecules downstream of $\mathrm{G}_{12 / 13}$ pathways. However, when pharmacological inhibitors of RhoA are used, they block these signaling molecules downstream of both $\mathrm{G}_{\mathrm{q}}$ and $\mathrm{G}_{12 / 13}$ and hence affect agonist-induced dense granule release. In the case of ADP, as it is a weak stimulator of $\mathrm{G}_{\mathrm{q}}$, a threshold levels of calcium and RhoA, that are required for dense granule release, are not reached. Hence, dense granule release does not occur until the threshold is reached by supplementing the signaling with $\mathrm{G}_{12 / 13}$ pathways.

In conclusion, we have shown that $\mathrm{G}_{12 / 13}$ pathways contribute to $\mathrm{PKC} \delta$ activation and platelet dense granule release through activation of RhoA. The potentiating effect of $\mathrm{G}_{12 / 13}$ pathways is maximal when $\mathrm{G}_{\mathrm{q}} / \mathrm{PLC}$ stimulation is limiting and becomes less important as the $\mathrm{G}_{\mathrm{q}} / \mathrm{PLC}$ pathways are maximally stimulated.

\section{Acknowledgments}

We thank Dr. Martin Schwartz, University of Virginia, for pGex-2T vector containing Rhotekin-Rho-binding domain. This work was supported by Research Grants HL81322, HL60683, and HL80444 from the National Institutes of Health (S. P. K.)

\section{References}

1. Packham MA. Role of platelets in thrombosis and hemostasis. Canadian journal of physiology and pharmacology 1994;72:278-84. [PubMed: 8069774]

2. Shattil SJ, Kashiwagi H, Pampori N. Integrin signaling: the platelet paradigm. Blood 1998;91:264557. [PubMed: 9531572]

3. Hourani SM, Cusack NJ. Pharmacological receptors on blood platelets. Pharmacological reviews 1991;43:243-98. [PubMed: 1956953]

4. Mills DC. ADP receptors on platelets. Thrombosis and haemostasis 1996;76:835-56. [PubMed: 8971999]

5. Molino M, Bainton DF, Hoxie JA, Coughlin SR, Brass LF. Thrombin receptors on human platelets. Initial localization and subsequent redistribution during platelet activation. The Journal of biological chemistry 1997;272:6011-7. [PubMed: 9038223]

6. Brass LF. More pieces of the platelet activation puzzle slide into place. The Journal of clinical investigation 1999;104:1663-5. [PubMed: 10606617]

7. Coughlin SR. How the protease thrombin talks to cells. Proceedings of the National Academy of Sciences of the United States of America 1999;96:11023-7. [PubMed: 10500117]

8. Coughlin SR. Protease-activated receptors in vascular biology. Thrombosis and haemostasis 2001;86:298-307. [PubMed: 11487018]

9. Holmsen, H. Hemostasis and Thrombosis: Basic Principles and Clinical Practice. Vol. 3. Colman, RW.; Hirsh, J.; Marder, VJ.; Salzman, EW., editors. JBLippincott Company; Philadelphia: 1994. p. 524-45.

10. Holmsen H. Significance of testing platelet functions in vitro. European journal of clinical investigation 1994;24(Suppl 1):3-8. [PubMed: 8013528]

11. Paul BZ, Jin J, Kunapuli SP. Molecular mechanism of thromboxane A(2)-induced platelet aggregation. Essential role for $\mathrm{p} 2 \mathrm{t}(\mathrm{ac})$ and alpha(2a) receptors. The Journal of biological chemistry 1999;274:29108-14. [PubMed: 10506165]

12. Kim S, Foster C, Lecchi A, Quinton TM, Prosser DM, Jin J, et al. Protease-activated receptors 1 and 4 do not stimulate G(i) signaling pathways in the absence of secreted ADP and cause human platelet aggregation independently of G(i) signaling. Blood 2002;99:3629-36. [PubMed: 11986217]

13. Shenker A, Goldsmith P, Unson CG, Spiegel AM. The G protein coupled to the thromboxane A2 receptor in human platelets is a member of the novel $\mathrm{Gq}$ family. The Journal of biological chemistry 1991;266:9309-13. [PubMed: 1851174] 
14. Hourani SM, Hall DA. Receptors for ADP on human blood platelets. Trends in pharmacological sciences 1994;15:103-8. [PubMed: 8016893]

15. Jin J, Kunapuli SP. Coactivation of two different G protein-coupled receptors is essential for ADPinduced platelet aggregation. Proceedings of the National Academy of Sciences of the United States of America 1998;95:8070-4. [PubMed: 9653141]

16. Offermanns S, Toombs CF, Hu YH, Simon MI. Defective platelet activation in G alpha(q)-deficient mice. Nature 1997;389:183-6. [PubMed: 9296496]

17. Rao AK, Kowalska MA, Disa J. Impaired cytoplasmic ionized calcium mobilization in inherited platelet secretion defects. Blood 1989;74:664-72. [PubMed: 2752141]

18. Gabbeta J, Yang X, Kowalska MA, Sun L, Dhanasekaran N, Rao AK. Platelet signal transduction defect with Galpha subunit dysfunction and diminished Galphaq in a patient with abnormal platelet responses. Proceedings of the National Academy of Sciences of the United States of America 1997;94:8750-5. [PubMed: 9238049]

19. Wang D, Feng J, Wen R, Marine JC, Sangster MY, Parganas E, et al. Phospholipase Cgamma2 is essential in the functions of B cell and several Fc receptors. Immunity 2000;13:25-35. [PubMed: 10933392]

20. Brass LF, Manning DR, Cichowski K, Abrams CS. Signaling through G proteins in platelets: to the integrins and beyond. Thrombosis and haemostasis 1997;78:581-9. [PubMed: 9198220]

21. Werner MH, Senzel L, Bielawska A, Khan W, Hannun YA. Diacylglycerol overcomes aspirin inhibition of platelets: evidence for a necessary role for diacylglycerol accumulation in platelet activation. Molecular pharmacology 1991;39:547-56. [PubMed: 2017154]

22. Walker TR, Watson SP. Synergy between $\mathrm{Ca} 2+$ and protein kinase $\mathrm{C}$ is the major factor in determining the level of secretion from human platelets. The Biochemical journal 1993;289( Pt 1):277-82. [PubMed: 8424766]

23. Jin J, Daniel JL, Kunapuli SP. Molecular basis for ADP-induced platelet activation. II The P2Y1 receptor mediates ADP-induced intracellular calcium mobilization and shape change in platelets The Journal of biological chemistry 1998;273:2030-4. [PubMed: 9442040]

24. Daniel JL, Dangelmaier C, Jin J, Ashby B, Smith JB, Kunapuli SP. Molecular basis for ADP-induced platelet activation. I Evidence for three distinct ADP receptors on human platelets. The Journal of biological chemistry 1998;273:2024-9. [PubMed: 9442039]

25. Fabre JE, Nguyen M, Latour A, Keifer JA, Audoly LP, Coffman TM, et al. Decreased platelet aggregation, increased bleeding time and resistance to thromboembolism in P2Y1-deficient mice. Nature medicine 1999;5:1199-202.

26. Klages B, Brandt U, Simon MI, Schultz G, Offermanns S. Activation of G12/G13 results in shape change and Rho/Rho-kinase-mediated myosin light chain phosphorylation in mouse platelets. The Journal of cell biology 1999;144:745-54. [PubMed: 10037795]

27. Moers A, Nieswandt B, Massberg S, Wettschureck N, Gruner S, Konrad I, et al. G13 is an essential mediator of platelet activation in hemostasis and thrombosis. Nature medicine 2003;9:1418-22.

28. Ren XD, Schwartz MA. Determination of GTP loading on Rho. Methods Enzymol 2000;325:26472. [PubMed: 11036609]

29. Rasmussen UB, Gachet C, Schlesinger Y, Hanau D, Ohlmann P, Van Obberghen-Schilling E, et al. A peptide ligand of the human thrombin receptor antagonizes alpha-thrombin and partially activates platelets. The Journal of biological chemistry 1993;268:14322-8. [PubMed: 8390990]

30. Bauer M, Retzer M, Wilde JI, Maschberger P, Essler M, Aepfelbacher M, et al. Dichotomous regulation of myosin phosphorylation and shape change by Rho-kinase and calcium in intact human platelets. Blood 1999;94:1665-72. [PubMed: 10477691]

31. Bae YS, Lee TG, Park JC, Hur JH, Kim Y, Heo K, et al. Identification of a compound that directly stimulates phospholipase C activity. Molecular pharmacology 2003;63:1043-50. [PubMed: 12695532]

32. Krjukova J, Holmqvist T, Danis AS, Akerman KE, Kukkonen JP. Phospholipase C activator $\mathrm{m}-3 \mathrm{M} 3 \mathrm{FBS}$ affects $\mathrm{Ca} 2+$ homeostasis independently of phospholipase $\mathrm{C}$ activation. British journal of pharmacology 2004;143:3-7. [PubMed: 15302681] 
33. Kawasaki T, Taniguchi M, Moritani Y, Hayashi K, Saito T, Takasaki J, et al. Antithrombotic and thrombolytic efficacy of YM-254890, a G q/11 inhibitor, in a rat model of arterial thrombosis. Thrombosis and haemostasis 2003;90:406-13. [PubMed: 12958608]

34. Taniguchi M, Nagai K, Arao N, Kawasaki T, Saito T, Moritani Y, et al. YM-254890, a novel platelet aggregation inhibitor produced by Chromobacterium sp. QS3666. The Journal of antibiotics 2003;56:358-63. [PubMed: 12817809]

35. Kim S, Jin J, Kunapuli SP. Relative contribution of G-protein-coupled pathways to protease-activated receptor-mediated Akt phosphorylation in platelets. Blood 2006;107:947-54. [PubMed: 16223779]

36. Dorsam RT, Kim S, Jin J, Kunapuli SP. Coordinated signaling through both G12/13 and G(i) pathways is sufficient to activate GPIIb/IIIa in human platelets. The Journal of biological chemistry 2002;277:47588-95. [PubMed: 12297512]

37. Nieswandt B, Schulte V, Zywietz A, Gratacap MP, Offermanns S. Costimulation of Gi- and G12/ G13-mediated signaling pathways induces integrin alpha IIbbeta 3 activation in platelets. The Journal of biological chemistry 2002;277:39493-8. [PubMed: 12183468]

38. Kim S, Jin J, Kunapuli SP. Akt activation in platelets depends on Gi signaling pathways. The Journal of biological chemistry 2004;279:4186-95. [PubMed: 14623889]

39. Gratacap MP, Payrastre B, Nieswandt B, Offermanns S. Differential regulation of Rho and Rac through heterotrimeric G-proteins and cyclic nucleotides. The Journal of biological chemistry 2001;276:47906-13. [PubMed: 11560922]

40. Benink HA, Bement WM. Concentric zones of active RhoA and Cdc42 around single cell wounds. The Journal of cell biology 2005;168:429-39. [PubMed: 15684032]

41. Nemoto Y, Namba T, Teru-uchi T, Ushikubi F, Morii N, Narumiya S. A rho gene product in human blood platelets. I Identification of the platelet substrate for botulinum C3 ADP-ribosyltransferase as rhoA protein. The Journal of biological chemistry 1992;267:20916-20. [PubMed: 1328215]

42. Moers A, Wettschureck N, Gruner S, Nieswandt B, Offermanns S. Unresponsiveness of platelets lacking both Galpha(q) and Galpha(13). Implications for collagen-induced platelet activation. J Biol Chem 2004;279:45354-9. [PubMed: 15326177]

43. Paul BZ, Daniel JL, Kunapuli SP. Platelet shape change is mediated by both calcium-dependent and - independent signaling pathways. Role of p160 Rho-associated coiled-coil- containing protein kinase in platelet shape change. J Biol Chem 1999;274:28293-300. [PubMed: 10497186]

44. Crosby D, Poole AW. Physical and functional interaction between protein kinase C delta and Fyn tyrosine kinase in human platelets. J Biol Chem 2003;278:24533-41. [PubMed: 12721299]

45. Murugappan S, Tuluc F, Dorsam RT, Shankar H, Kunapuli SP. Differential role of protein kinase C delta isoform in agonist-induced dense granule secretion in human platelets. J Biol Chem 2004;279:2360-7. [PubMed: 14578358]

46. Le Good JA, Ziegler WH, Parekh DB, Alessi DR, Cohen P, Parker PJ. Protein kinase C isotypes controlled by phosphoinositide 3-kinase through the protein kinase PDK1. Science 1998;281:20425. [PubMed: 9748166]

47. Parekh D, Ziegler W, Yonezawa K, Hara K, Parker PJ. Mammalian TOR controls one of two kinase pathways acting upon nPKCdelta and nPKCepsilon. J Biol Chem 1999;274:34758-64. [PubMed: 10574945]

48. Parekh DB, Ziegler W, Parker PJ. Multiple pathways control protein kinase C phosphorylation. Embo J 2000;19:496-503. [PubMed: 10675318]

49. Rybin VO, Sabri A, Short J, Braz JC, Molkentin JD, Steinberg SF. Cross-regulation of Novel Protein Kinase C (PKC) Isoform Function in Cardiomyocytes. ROLE OF PKCepsilon IN ACTIVATION LOOP PHOSPHORYLATIONS AND PKCdelta IN HYDROPHOBIC MOTIF PHOSPHORYLATIONS. J Biol Chem 2003;278:14555-64. [PubMed: 12566450]

50. Tan M, Xu X, Ohba M, Ogawa W, Cui MZ. Thrombin rapidly induces protein kinase D phosphorylation, and protein kinase C delta mediates the activation. J Biol Chem 2003;278:2824-8. [PubMed: 12431976]

51. Brass LF, Joseph SK. A role for inositol triphosphate in intracellular Ca2+ mobilization and granule secretion in platelets. The Journal of biological chemistry 1985;260:15172-9. [PubMed: 3934155]

52. Brass LF, Hoxie JA, Manning DR. Signaling through G proteins and G protein-coupled receptors during platelet activation. Thrombosis and haemostasis 1993;70:217-23. [PubMed: 8236108] 
53. Leon C, Hechler B, Freund M, Eckly A, Vial C, Ohlmann P, et al. Defective platelet aggregation and increased resistance to thrombosis in purinergic P2Y(1) receptor-null mice. The Journal of clinical investigation 1999;104:1731-7. [PubMed: 10606627]

54. Paul BZ, Daniel JL, Kunapuli SP. Platelet shape change is mediated by both calcium-dependent and -independent signaling pathways. Role of p160 Rho-associated coiled-coil-containing protein kinase in platelet shape change. The Journal of biological chemistry 1999;274:28293-300. [PubMed: 10497186]

55. Leng L, Kashiwagi H, Ren XD, Shattil SJ. RhoA and the function of platelet integrin alphaIIbbeta3. Blood 1998;91:4206-15. [PubMed: 9596668] 


\section{A}

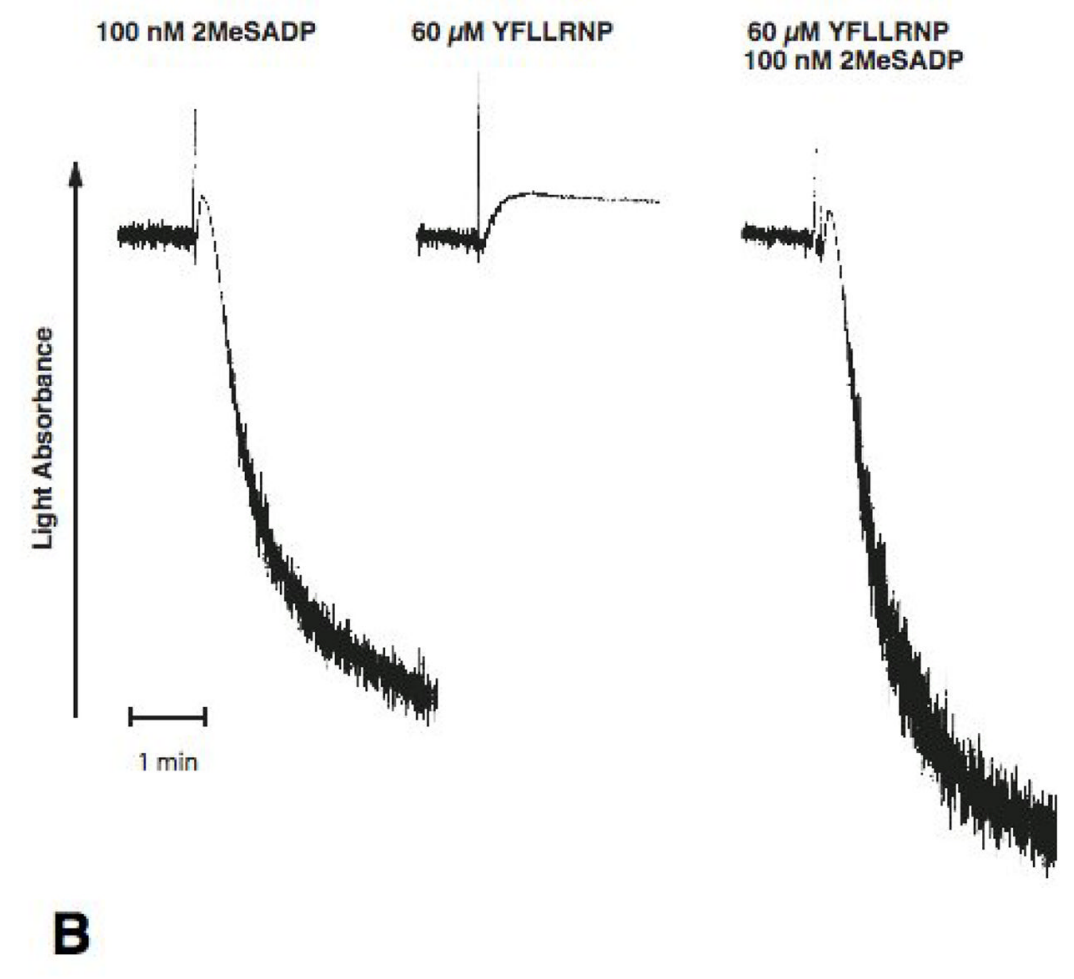

$100 \mathrm{nM}$ 2MeSADP

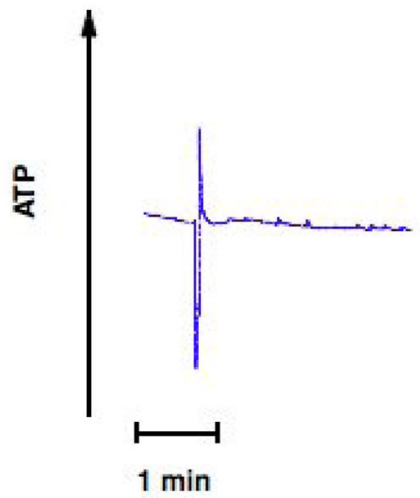

$60 \mu \mathrm{M}$ YFLLRNP

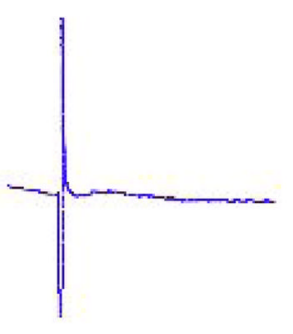

$60 \mu \mathrm{M}$ YFLLRNP

$100 \mathrm{nM} 2 \mathrm{MeSADP}$

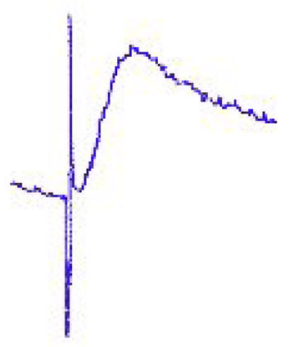

Fig. 1. Effect of $\mathrm{G}_{12 / 13}$ activation on 2MeSADP-induced platelet dense granule release in human platelets

Aspirin-treated and washed human platelets were stimulated with $100 \mathrm{nM}$ 2MeSADP, $60 \mu \mathrm{M}$ YFLLRNP or $60 \mu \mathrm{M}$ YFLLRNP+100 nM 2MeSADP at $37^{\circ} \mathrm{C}$ while stirring. Platelet aggregation (A) and secretion (B) were measured in a Lumi aggregometer. The tracings are representative of data from at least three independent experiments. 
A

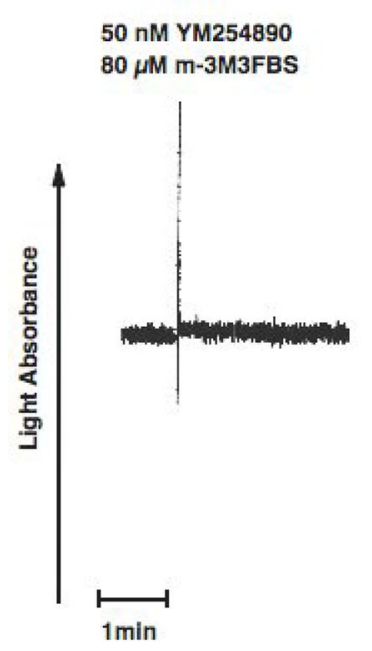

$50 \mathrm{nM}$ YM254890

$50 \mathrm{nM}$ YM254890

$500 \mu \mathrm{M}$ AYPGKF

M m-3M3FBS

$500 \mu \mathrm{M}$ AYPGKF

B

50 nM YM254890

$50 \mathrm{nM}$ YM254890

$80 \mu \mathrm{M}$ m-3M3FBS

$500 \mu \mathrm{M}$ AYPGKF
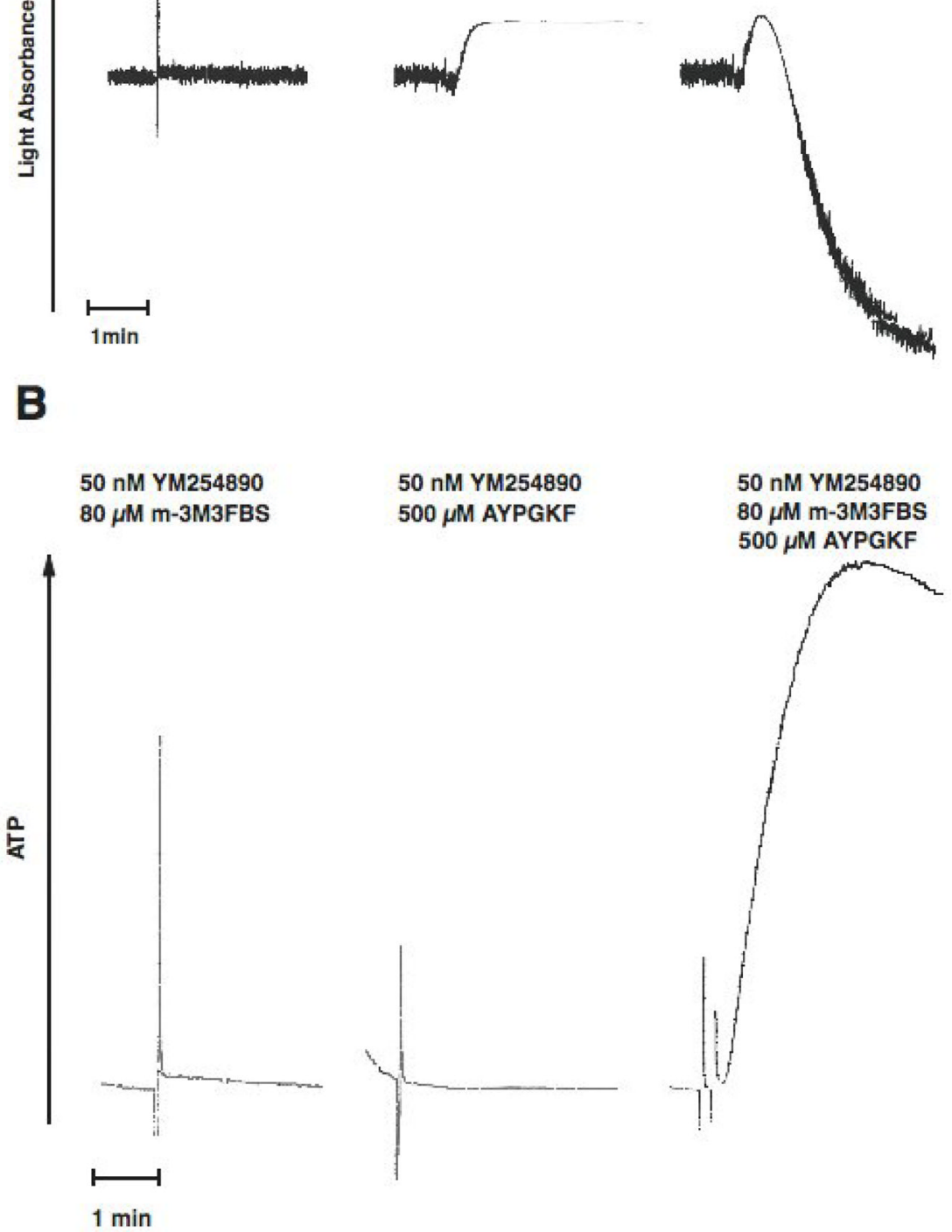

$50 \mathrm{nM}$ YM254890

$80 \mu \mathrm{M}$ m-3M3FBS $500 \mu \mathrm{M}$ AYPGKF
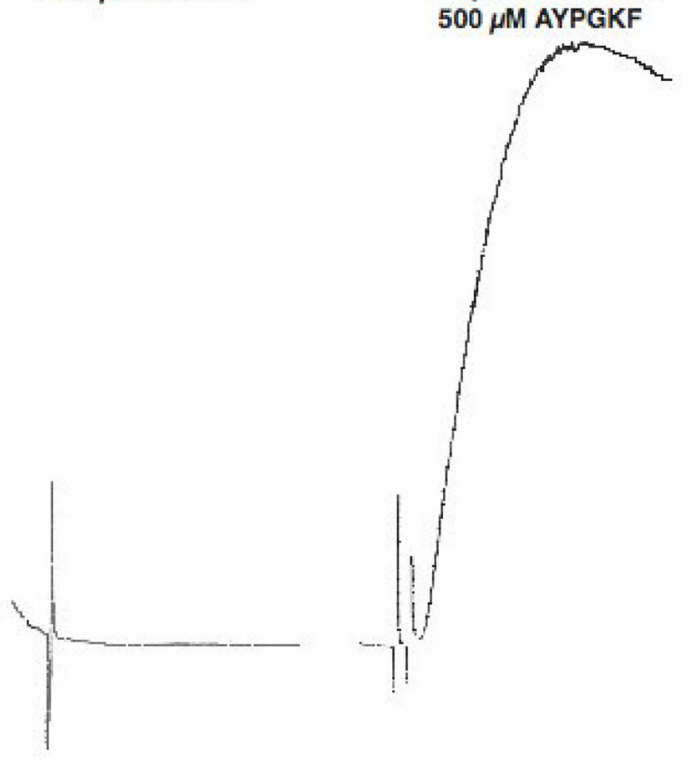

Fig. 2. Effect of selective activation of Phospholipase $C$ and $G_{12 / 13}$ pathways on platelet dense granule release in human platelets

Aspirin-treated and washed human platelets were stimulated with $80 \mu \mathrm{M}$ m-3MFBS, $500 \mu \mathrm{M}$ AYPGKF or $80 \mu \mathrm{M}$ m-3MFBS $+500 \mu \mathrm{M}$ AYPGKF at $37^{\circ} \mathrm{C}$ while stirring. Platelet samples were incubated with $50 \mathrm{nM}$ YM254890 $\left(\mathrm{G}_{\mathrm{q}}\right.$ protein inhibitor $)$ at $37^{\circ} \mathrm{C}$ for $5 \mathrm{~min}$ before the addition of agonists. Platelet aggregation $(\mathrm{A})$ and secretion $(\mathrm{B})$ were measured in a Lumi aggregometer. The tracings are representative of data from at least three independent experiments. 
A

$500 \mu \mathrm{M}$ AYPGKF

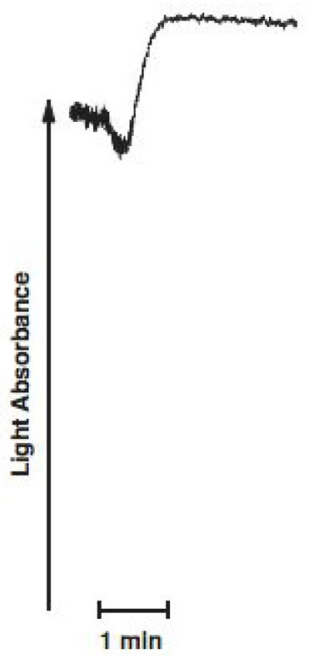

$80 \mu \mathrm{M}$ m-3M3FBS

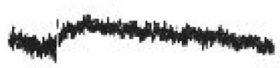

$500 \mu \mathrm{M}$ AYPGKF

$80 \mu \mathrm{M}$ m-3M3FBS

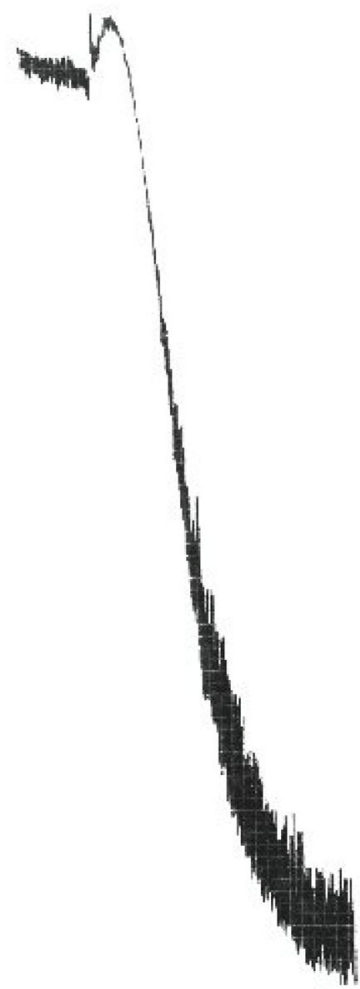


B

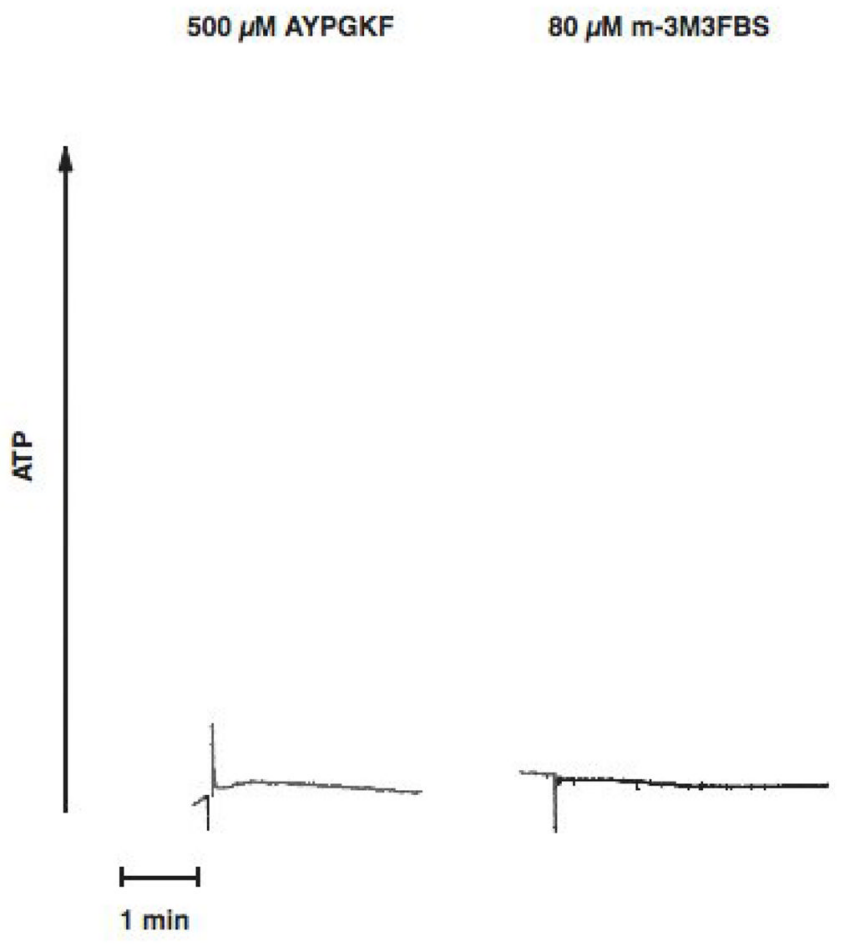

$500 \mu \mathrm{M}$ AYPGKF

$80 \mu \mathrm{M}$ m-3M3FBS

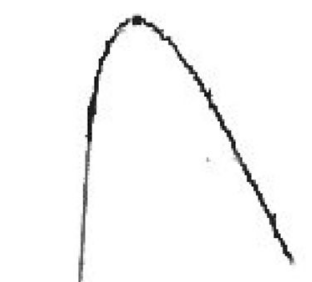


C

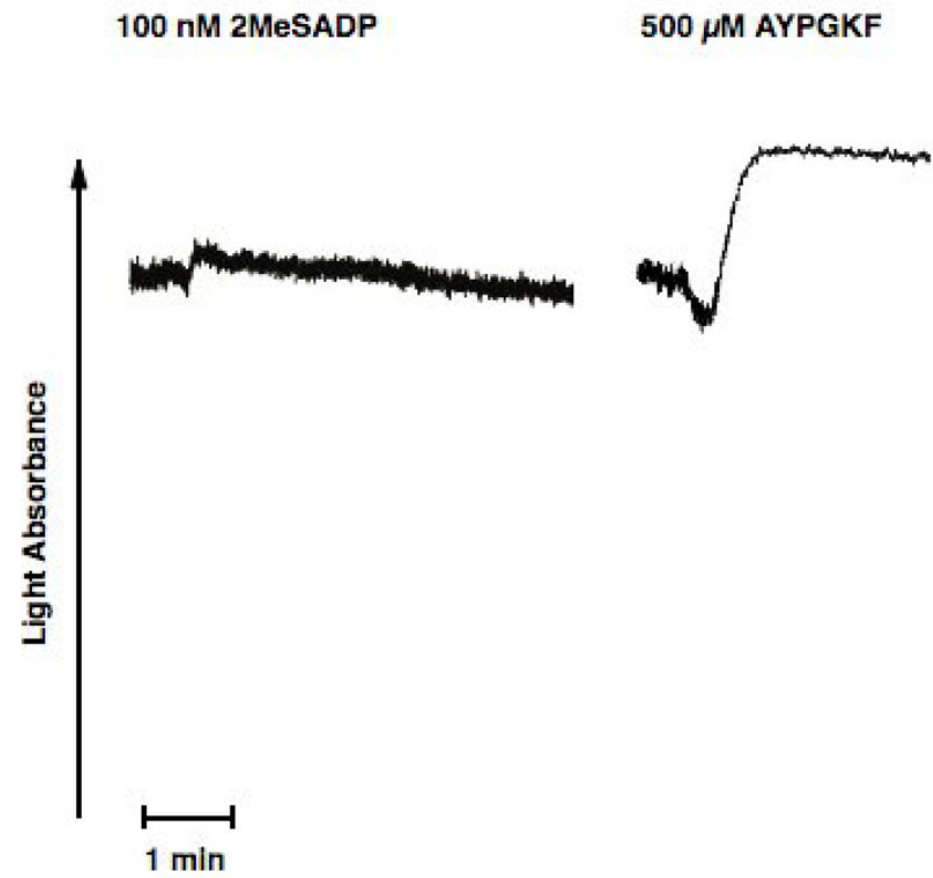

$100 \mathrm{nM}$ 2MeSADP
$500 \mu \mathrm{M}$ AYPGKF

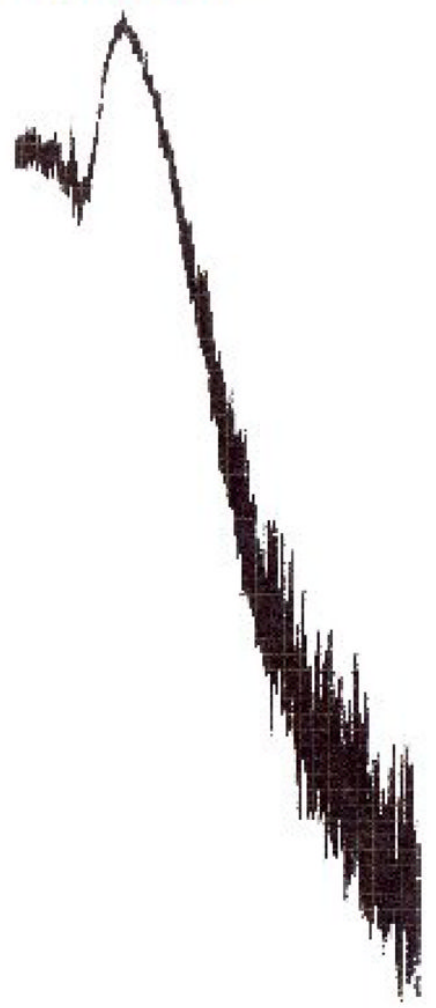

D

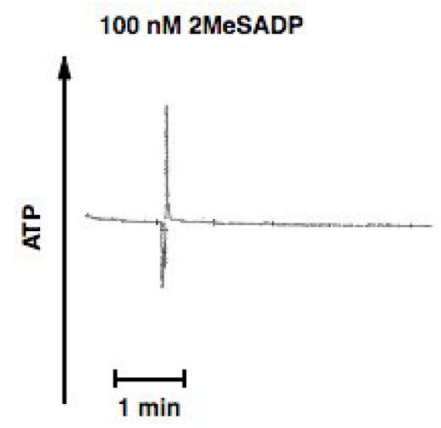

$500 \mu \mathrm{M}$ AYPGKF

$100 \mathrm{nM}$ 2MeSADP

$500 \mu \mathrm{M}$ AYPGKF
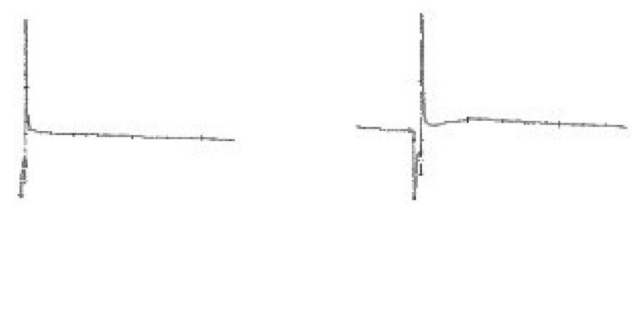

Fig. 3. Effect of selective activation of Phospholipase $C$ and $G_{12 / 13}$ pathways on platelet dense granule release in $\mathbf{G} \alpha_{\mathbf{q}}$ null mouse platelets

Aspirin-treated and washed $\mathrm{Gq}-/-$ mouse platelets were stimulated with $80 \mu \mathrm{M} \mathrm{m}-3 \mathrm{MFBS}$, $500 \mu \mathrm{M}$ AYPGKF or $80 \mu \mathrm{M}$ m-3MFBS+500 $\mu \mathrm{M}$ AYPGKF (A and B), $100 \mathrm{nM} 2 \mathrm{MeSADP}$, $500 \mu \mathrm{M}$ AYPGKF or $100 \mathrm{nM} 2 \mathrm{MeSADP}+500 \mu \mathrm{M}$ AYPGKF $\left(\mathrm{C}\right.$ and D) at $37^{\circ} \mathrm{C}$ while stirring. Platelet aggregation (A and $C$ ) and secretion (B and D) were measured in a Lumi aggregometer. The tracings are representative of data from at least three independent experiments. 
A

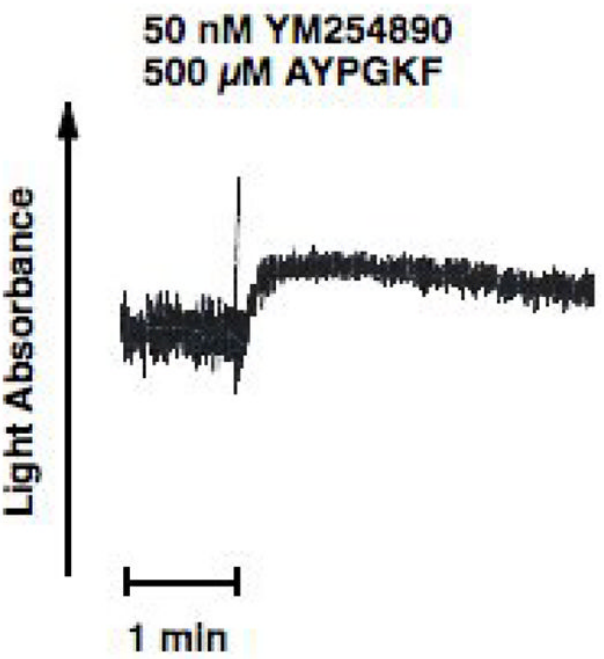

$20 \mu \mathrm{g} / \mathrm{ml}$ Exoenzyme C3 Transferase $50 \mathrm{nM}$ YM254890 $500 \mu \mathrm{M}$ AYPGKF

B

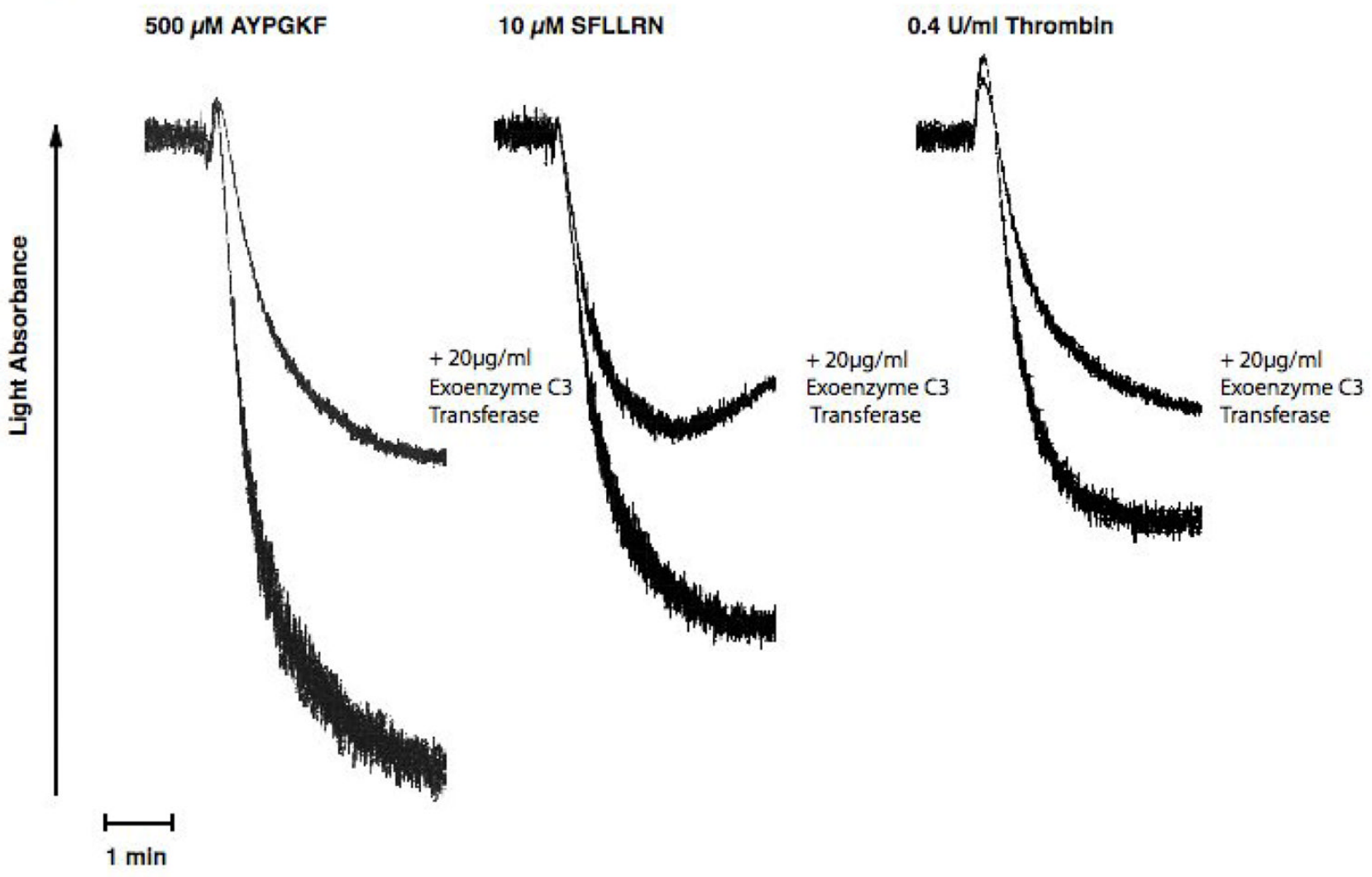


C

$500 \mu \mathrm{M}$ AYPGKF

$20 \mu \mathrm{g} / \mathrm{ml}$ Exoenzyme C3 Transferase $500 \mu \mathrm{M}$ AYPGKF

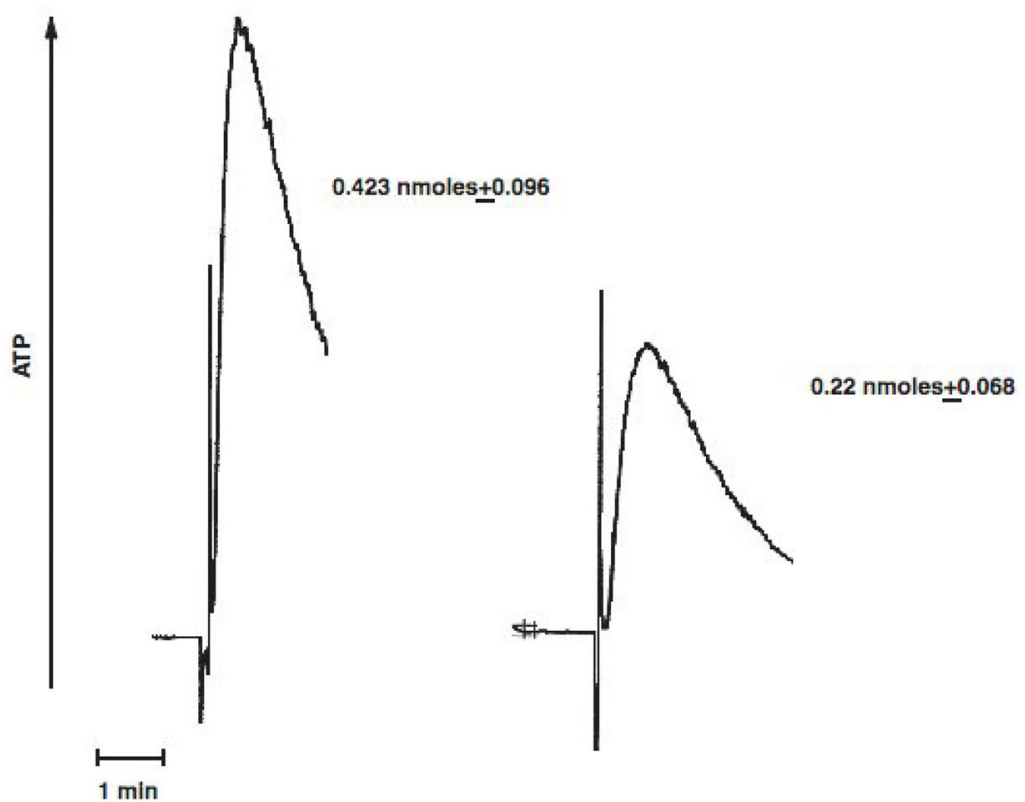


D

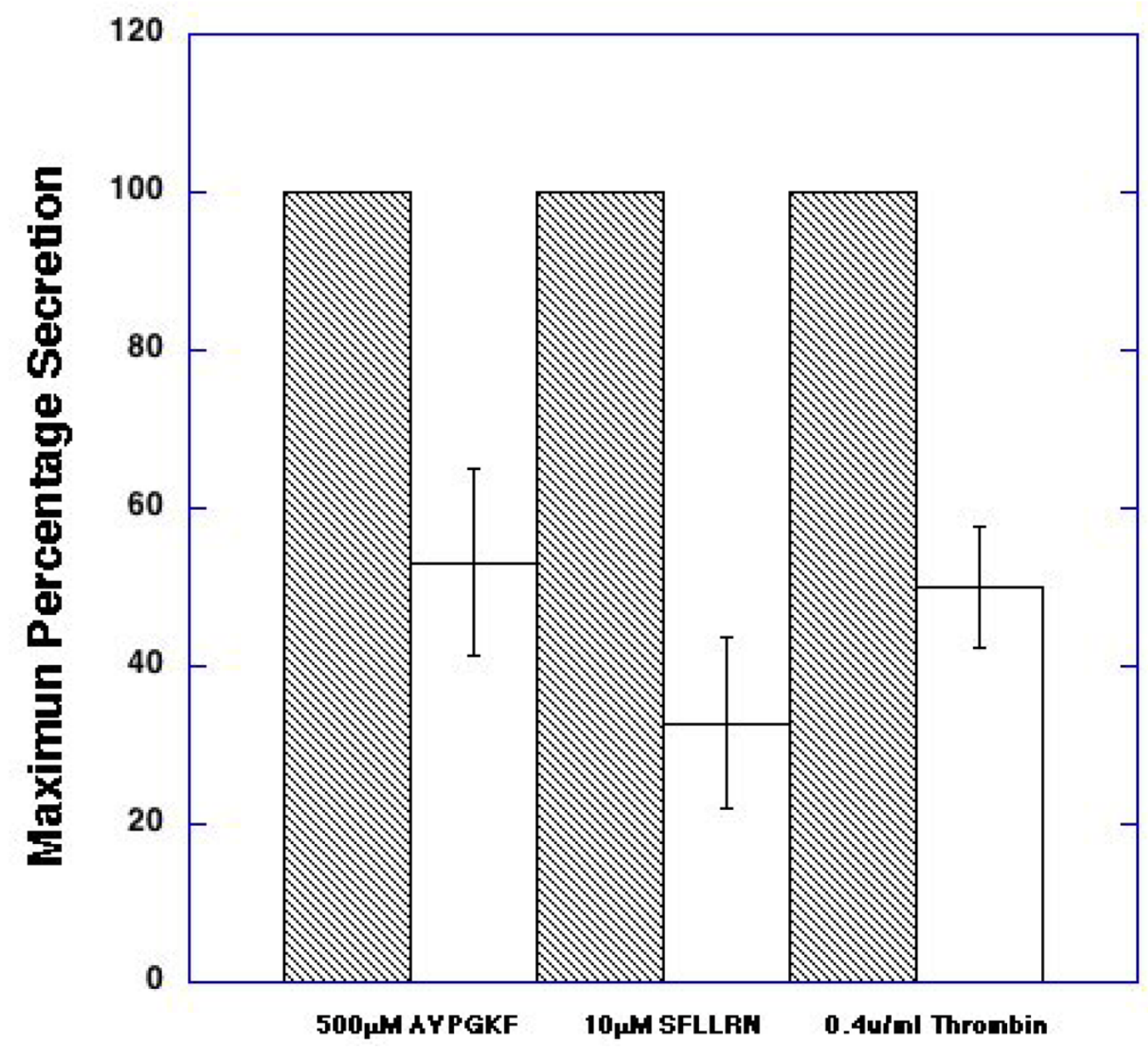

Fig. 4. Effect of C3 Transferase on PAR-mediated dense granule secretion in human platelets Aspirin-treated and washed human platelets were stimulated with $500 \mu \mathrm{M}$ AYPGKF, $10 \mu \mathrm{M}$ SFLLRN or $0.2 \mathrm{U} / \mathrm{ml}$ Thrombin at $37^{\circ} \mathrm{C}$ while stirring. Platelet samples were incubated with $20 \mu \mathrm{g} / \mathrm{ml}$ exoenzyme C3 Transferase at $37^{\circ} \mathrm{C}$ for $4 \mathrm{hrs}$ before the addition of agonists. Platelet shape change (A) aggregation (B) and secretion (C and D) were measured in a Lumi aggregometer. The tracings are representative of data from at least three independent experiments. The secretion data in panel D were normalized to the maximum secretion (taken as $100 \%)$. 
A

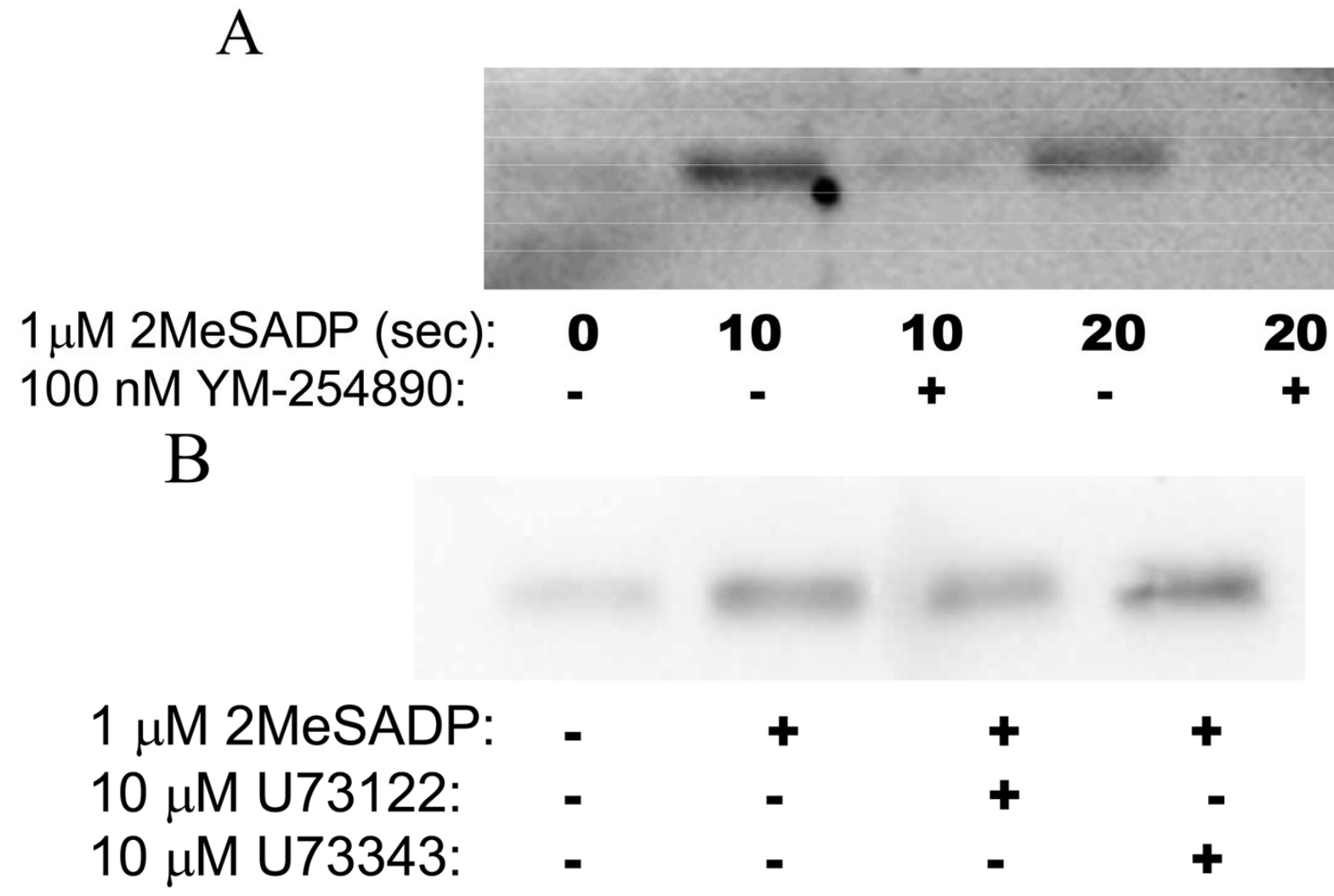

Fig. 5. Rho A activation downstream of Gq pathways

A) Aspirin-treated and washed human platelets were stimulated with $1 \mu \mathrm{M} 2 \mathrm{MeSADP}$ at $37^{\circ}$ $\mathrm{C}$ for the indicated times with or without 5 minute pre-incubation with the Gq inhibitor YM-254890. Active RhoA was then assayed using agarose coupled GST-Rhotekin-RBD and Western Blotting probing for RhoA. (B) GST-pull down of active RhoA was performed on lysates from unstimulated platelets or platelets pre-incubated with or without the PLC inhibitor U73122 or its control compound (U73343) for 8 minutes prior to activation with 2MeSADP for $10 \mathrm{sec}$. Active RhoA was detected via Western Blotting with an anti-Rho monoclonal antibody. The blot is representative of data from at least three independent experiments. 


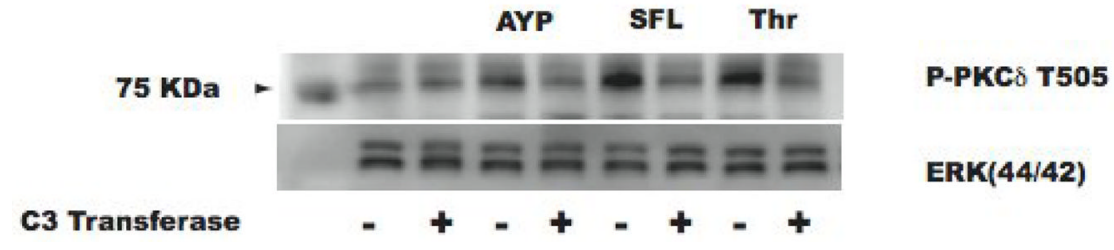

Fig. 6. Effect of C3 Transferase on PAR-mediated activation-dependent PKC $\delta$ phosphorylation Aspirin-treated and washed human platelets were stimulated with $250 \mu \mathrm{M}$ AYPGKF, $10 \mu \mathrm{M}$ SFLLRN, or $0.2 \mathrm{U}$ Thrombin at $37^{\circ} \mathrm{C}$ while stirring. Platelet samples were incubated with 20 $\mu \mathrm{g} / \mathrm{ml}$ exoenzyme C3 Transferase at $37^{\circ} \mathrm{C}$ for $4 \mathrm{hrs}$ before the addition of agonist. PKC $\delta$ activation was measured by detecting T-505 phosphorylation by western blotting using phospho-specific antibodies. Total Erk1/2 was used as lane loading control. The blot is representative of data from at least three independent experiments. 


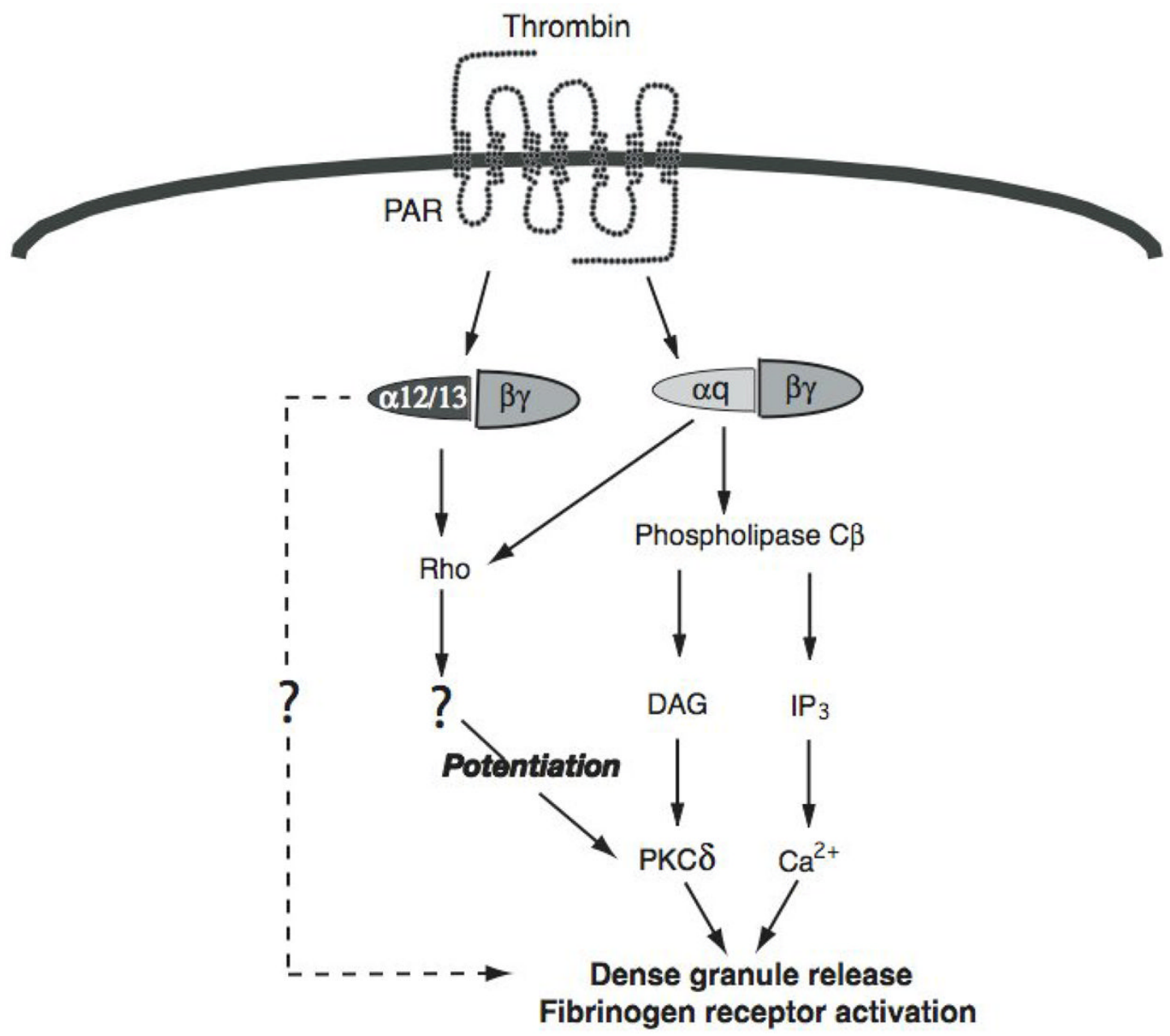

Fig. 7. Model depicting RhoA pathways are activated downstream of both $G_{q}$ and $G_{12 / 13}$ pathways PAR activation by thrombin results in activation of $G_{q}$ and $G_{12 / 13}$ pathways. $G_{12 / 13}$ pathways potentitate the $\mathrm{G}_{\mathrm{q}}$-mediated dense granule release and fibrinogen receptor activation. In the absence of $\mathrm{G}_{\mathrm{q}}$ pathways these events do not occur. Maximum stimulation of $\mathrm{G}_{\mathrm{q}}$ pathways by PARs can circumvent requirement of $\mathrm{G}_{12 / 13}$ pathways due to possible direct activation of RhoA pathways. 